\title{
Prayers, Commentaries, and the Edification of the Ottoman Supplicant
}

\author{
Guy Burak
}

In the growing scholarly corpus on Ottoman Islam remarkably little attention has been paid to prayers, invocations, and supplications. ${ }^{1}$ But the scholarly interest stands in inverse relation to the amount of manuscripts containing prayers and supplications of various sorts. Even a cursory overview of library catalogs from Turkey, the Middle East, the Balkans, Europe, and North America reveals a sizable and diverse textual corpus that has remained, by and large, unexamined. Consider, for instance, the inventory of the library of Sultan Bāyezīd II (d. 908/1512). The list of prayer books, invocations, amulets, and talismanic shirts is one of the longest in the inventory (about 200 items) and includes titles in Arabic, Persian, and Turkish. ${ }^{2}$

The lack of attention to this fairly extensive textual corpus may be attributed, at least in part, to the texts' formulaic and repetitive nature. However, as Tijana Krstić and Derin Terzioğlu have shown in their respective studies of Ottoman 'ilm-i hạ $l s,{ }^{3}$ devotional literature - prayer books and invocations included-is theologically charged and the history of its production and circulation offers a unique glimpse into important aspects of Ottoman Islam. In this essay, then, I seek to illustrate the significance of the vast and diverse corpus of supplications, invocations, and prayers for gaining a better understanding of certain sensibilities that emerged mainly, but surely not exclusively, in the core lands of the empire from the tenth/sixteenth through the twelfth/eighteenth centuries.

Numerous terms were used to refer to different types of prayers, supplications, and invocations, although they were occasionally used somewhat incon-

1 This is the case not only in Ottomanist historiography but in Islamic studies more generally. Katz, Prayer 29-43; Padwick, Muslim devotions; McGregor, On the literature. For the Ottoman period, there are some exceptions: Bain, The late Ottoman En‘am-ı şerif; Gruber, A pious cureall.

2 Burak, The section on prayers 341-366. Likewise, Konrad Hirschler has observed that prayer books made up a great proportion of the collection of the seventh/thirteenth-century Ashrafiyya Library in Damascus. Hirschler, The written word 147-149.

3 Terzioğlu, Where 'ilm-i hă $l$; Krstić, From shahāda to 'aqìda; and Krstić's contribution to this volume. 
sistently: șalāt (pl. șalāwāt, Tr. șalavāt), du'ā (pl. ad'iya, Tr. ed'iye), ḩizb (pl. ahzāa), and wird (pl. awräd, Tr. evrād). Moreover, it is not fully clear at this point how exactly each of these compilations and genres was employed. It is possible that some texts were considered more petitionary, intended to persuade God to intervene on behalf of the supplicant on specific issues, while others were more supererogatory in nature. However, it is quite difficult to draw a clear line between different uses of the devotional and supplicatory texts as it is quite likely that there were cases in which the same text was used for different purposes. ${ }^{4}$

The Ottoman devotional corpus also included a significant number of commentaries (usually referred to as sharh, pl. shurūh h) on prayers, invocations, and supplications. It is on these commentaries that I would like to concentrate in this chapter, with the intention of exploring the relationship between recitation, the understanding of the recited invocations/prayers, and piety. In particular, I would like to examine several compilations from the tenth/sixteenth through the twelfth/eighteenth centuries that seem to have enjoyed great popularity, from the popular manual on prayers by the famous tenth/sixteenthcentury Ottoman chief mufti Ebū's-su'ūd Efendi (d. 982/1574) to several twelfth/eighteenth-century commentaries on Muhammad ibn Sulaymān alJazūlī's (d. 870/1465) Dalāil al-khayrāt wa-shawāriq al-anwār and 'Alī al-Qārī al-Harawi's (d. 1014/1606) al-Hizb al-azam wa al-wird al-afkham. These compilations were intended to assist the supplicant to perform her supplication properly.

The question of understanding the recited invocations and devotional texts centers on the question of the ma' $\bar{a} \bar{a}$. In a recent and insightful study of the theories of $m a^{\prime} n \bar{a}$ in the fifth/eleventh century, Alexander Key has drawn attention to the centrality of this concept in a wide range of disciplines in the Arabic scholarly tradition, from lexicography to theology and logic. As opposed to the more common translation of the word as "meaning," Key has proposed to translate $m a^{\prime} n \bar{a}$ as mental content that could be accessed and expressed, though not necessarily accurately, by language. ${ }^{5}$ In the following pages, I hope

4 As Richard McGregor has noticed for the Mamluk period, "although the terminology is inconsistent, with prayers referred to by more than one term, the genre as a whole is clearly identifiable as consisting of supererogatory petitionary prayer compositions," Notes on the literature 201. Furthermore, it is worth reiterating, the compiler of the aforementioned inventory of the library of Sultan Bāyezìd II recorded the invocations and prayers in the same section of the inventory with amulets, talismanic shirts, and works on lettrism, suggesting that these texts were used, at least in certain circles, as part of a set of occult practices.

5 Key, Language between god 38. 
to demonstrate a range of perceptions of the relationship between understanding the recited text and valid/effective recitation that coexisted throughout the core lands of the empire (and probably beyond). Some of the Ottoman thinkers emphasized the importance of understanding the $m a^{i} n \bar{a}$ of the recited text, while others seem to have assumed that the effective recitation does not require such understanding. It appears to me that the gap between language (lafz) and mental content (ma'na $)$, which was central in the writings of the fifth/eleventh-century (and later) thinkers, and the emphasis of certain Ottoman commentators on understanding the $m a^{n} n \bar{a}$ raise intriguing questions with regard to the latter's understanding of the cognitive effect of the recited words on the reciters.

In this short chapter, I will concentrate on a the tenth/sixteenth-century manual by Ebū's-su'ūd Efendi on the one hand and the twelfth/eighteenthcentury commentaries on the Daläil and the Hizb on the other and their respective perceptions of the relationship between understanding the devotional text and effective recitation. Such a comparison suggests that commentarial practices that had been fairly limited to Sufi circles became more prevalent among the broader segments of Ottoman society in the late eleventh/seventeenth and twelfth/eighteenth centuries.

My interest in the circulation of the Dalāil and its commentaries in the Ottoman lands has led me to devote special attention in what follows to intellectual and devotional developments in the first half of the twelfth/eighteenth century. This chapter, then, joins several recent studies that cast new light on early twelfth/eighteenth-century Ottoman Islam. Most notably, Marlene Kurz's study has drawn attention to several Sufi thinkers, like the marginal Sufi preacher Fażlizzāde 'Alī (d. after 1153/1740), the focus of her study, as well as Muhammad Saçaḳlizāde (d. 1145/1732-1733), whom we shall meet below, who believed that their period was suffering from religious confusion and disorder. $^{6}$ In response to the disorder, these Sufi thinkers thought they should guide whoever is in need of guidance on the straight path (irshād) based on their understanding of what characterized such a path. ${ }^{7}$ As a result, Kurz has argued, these thinkers (and others) aspired to popularize certain Sufi doctrines and practices throughout broader segments of Ottoman society. ${ }^{8}$ Moreover, the study of Islamic thought and practices in the this period may illustrate the par-

6 Kurz, Ways to heaven 53-54. For an overview of major intellectual trends in the core lands of the empire in the eleventh/seventeenth and twelfth/eighteenth centuries, see Artan, Forms and forums.

7 Kurz, Ways to heaven 133 .

8 Ibid. 112. 
ticularities of the Ottoman confession building project of the ninth/fifteenth through the eleventh/seventeenth centuries: despite clear continuities in terms of texts, genres, and practices, the Ottoman dynasty and its ruling elite appear to have played a different, perhaps somewhat less central, role by the early twelfth/eighteenth century than the one they had played in earlier centuries (on this issue, see also Ünver Rüstem's paper in this volume). However, as the commentaries I will discuss suggest, questions about spiritual wellbeing, devotion, and faith continued to concern many in the Ottoman domains. In other words, this essay seeks to draw attention to the involvement (or lack thereof) of different actors in different registers of Ottoman Islam and in different time periods: while the Ottoman dynasty and its learned hierarchy may have been interested in regulating certain practices and discourses in specific contexts, they may have been much less eager or able to do so with regard to other discourses and in other time periods (and possibly in other places throughout the empire).

Finally, this chapter also seeks to contribute to the study of devotional sensibilities in the Ottoman Empire in general and in the context of the historiography on confession building (or "confessionalization") in particular. Specifically, by studying the commentaries on prayers and invocations, my intention is to draw attention to the diversity of practices and ideas that fall under the fairly general term of "devotion." I hope that the examination of the different approaches to the understanding of recited texts will broaden the discussion on perceptions of the relationship between belief/understanding and performative deeds/speech acts that prevailed in the Ottoman lands and, perhaps, elsewhere.

\section{A Note on Prayers and Commentaries}

In recent years, several studies have been devoted to the function of different types of commentaries and commentarial practices, from Quranic exegesis (tafsir) to glosses (häshiyya), in the Islamic tradition of the so-called "postclassical" period. ${ }^{9}$ These studies have tried to correct an (Orientalist) view of commentaries as "no more than stale expositions of the works of revered masters of a bygone age" and to demonstrate the commentator's creativity and

9 See, for example, the special issue edited by Asad Q. Ahmed and Margaret Larkin on "The Hāshiyya and Islamic intellectual history," Oriens 41 (2013). See also van Lit, An Ottoman commentary. 
innovation..$^{10}$ However, the study of commentaries in the Islamic tradition has tended to privilege certain textual corpora-such as hadith, figh, theology, tafsir , literature, and philosophy — while ignoring others. The focus on these fields of knowledge may be attributed, to some extent at least, to historiographical/scholarly hierarchies that consider certain Islamic sciences more respectable than others.

In this context, Richard McGregor's short yet groundbreaking study of Mamluk commentaries on the "revealed" or inspired prayer compositions of the great Sufi masters deserves special mention. These prayer compositions became fairly common after the sixth/twelfth century and were associated with saintly figures, usually senior members of their respective Sufi networks or even the eponymous founders of Sufi paths. The prayer cycles' tone is often petitionary and the content is often derived from the Quran (as the term wird indicates) and/or the prophetic tradition (hadith). As McGregor explains, "the Qur'anic passages in these prayer texts vary in length and style, and they are also edited in order to preserve the voice and syntax of the prayer narrative ... Used this way, the Qur'anic text is both an integral component of the prayer text, and yet is altered to serve in its new context."11

Within various Sufi networks, fairly complex systems of commentaries on the prayer/ invocation compositions emerged. Commentaries have been assigned different terms, including tafsìr, ta'līqa, tahdhīb, mukhtașar, hawāshī, and tașhịh, but, as in the Ottoman period, the most commonly used term was sharh. In addition to clarifying the text of prayers and invocations to members of the network, the Mamluk commentaries sought to establish the saintly authority of the author. It is for this reason that many commentaries include hagiographical materials about the author and reports on miraculous events caused by the recitation of the prayer/invocation. ${ }^{12}$

My inquiry is inspired to a considerable extent by McGregor's examination of the Mamluk Sufi commentaries on prayers and invocations. My main interest, however, is not in the prayer compilation that circulated within Sufi networks but in commentaries on prayer compilations that were intended for a broader audience. While some of the texts examined below, like al-Jazūlì's Dalāil al-khayrāt, are quite similar to the Sufi prayer compilations of the Mamluk and Ottoman periods, other works, such as Ebū's-su'ūd's Du'ānāme, are different in structure and content. It is precisely because of the fairly broad

\footnotetext{
10 Ahmed and Larkin, The hashiya 213-214.

11 McGregor, Notes on the literature 205.

12 Ibid. 208. This practice continued in the Ottoman period. Most Ottoman commentaries on Dalä'il al-khayrät include a biography of al-Jazūlì.
} 
circulation of the texts examined here that I am especially concerned with the issues of edifying the reciter and establishing the proper relationship between the recitation and the correct understanding of the recited text.

At some point between $968 / 1561$ and $972 / 1565$, the renowned şeyhül-islām Ebū's-su'ūd Efendi penned a prayer manual for the empire's grand vizier, Semiz 'Alī Paşa (served as grand vizier from 968-972/1561-1565, d. 972/1565). In the following decades and centuries, the manual became quite popular, as the numerous extant copies suggest. ${ }^{13}$ Despite the work's honorable dedicatee, "the Asaf of the time," the chief mufti emphasizes in his introduction to the manual that the prayer $\left(d u^{c} \bar{a}\right)$ is intended to commemorate the Prophet and argues that the supplication is an individual obligation ( far $\dot{z}-\iota$ 'ayn) that both members of the elite and the commoners are required to perform. ${ }^{14} \mathrm{It}$ is possible that the jurist and the grand vizier intended the work to circulate widely, and it is, perhaps, for this reason that Ebū's-su'ūd Efendi insisted on writing his manual in Turkish: "I have [selected a] limited [number] of traditions [transmitted] from the Prophet, and translated their commentary into Turkish, so that in moments of prayer and worship and in auspicious times and in important [instances] offering [a prayer] would be easy and its [the prayer's] aid would be imminent."15 Indeed, Ebü's-su'ūd's list of supplicants is very comprehensive in terms of their social rank: a just imam (imām-i 'ädil), the learned (ehl-i Kur'ān olan kimesne), the pious (or Sufi, șālih), recent converts, fathers, sons, and the sick. ${ }^{16}$

After a fairly brief discussion of the definition of $d u^{\prime} \bar{a}$, Ebū's-su'ūd describes the preconditions for a successful supplication: the supplicant, for example, has

13 For an incomplete list of copies of the Du'ānāme see Kaleli, Du'ā-nāme 5-14. I am grateful to Evren Sünnetçioğlu for bringing this thesis to my attention. See also Demir, Devlet- $i$ Aliyye'nin 51. In addition, I have consulted Süleymaniye Kütüphanesi, Ms Laleli 1534, which does not appear in Kaleli's and Demir's lists.

14 "Anı du'āda hayırla yād eylemek kâffe-i enām, ve cümle-i havāșș ü 'avāmm üzerine farż-ı 'ayn lāzimü'l-edā.” Kaleli, Du'ā-nāme 112.

15 'Resūlu'-llāh șalla Allāhu 'aleyhi ve sellemden rivāyet eylediklerin iktisār idüp şerhleri Türkī dilince tercüme eyledim ki evkāt-i du'ā ve 'ibādātda ve ezmān-i mesāliḥa ve mühimmātda me'üneti kalīl ve ma'üneti 'ale't-te'cil ola." Ibid. 113. It is worth noting that this was not the only work 'Alī Semiz Paşa commissioned in Turkish: while serving as the Ottoman governor of Egypt (956-961/1549-1554), he was presented with a work on the Ottoman construction projects in Mecca in "clear Turkish." See Burak, Between Istanbul and Gujarat 315 .

16 Kaleli, Du'ā-nāme 120. 
to repent, give alms (or perform a good deed), believe in the prayer he recites, praise God at the beginning of the prayer and say "Amen" at the end of the prayer, recite the prayer slowly, raise her hands during the prayers, and wipe her face at the end. He then moves on to list the auspicious times during which the prayer is more likely to be answered (evkāt-i icābet), such as the first night of the month of Rajab and night of the middle of Sha'ban, and the following day; the Laylat al-Qadr (celebrated on the twenty-seventh day of Ramadan to commemorate the beginning of the revelation of the Quran to the Prophet) and the following day; and Thursday nights and Fridays during Ramadan. During the year, the time period between the khutba and the end of the ritual/canonical prayer on Friday and the last third of the night are also special times for supplication, as are the moments after the call for prayer, after the canonical prayer, and after the recitation of the Quran. Battles (ḳtāl fı sebilillāh) are also considered auspicious times. Finally, Ebū's-su'ūd provides his reader with a sign that God accepted her supplication ('alāmet-i kabül): If the supplicant's pain is relieved, she may interpret the relief as a sign of her prayer's acceptance. ${ }^{17}$

The body of the Du'āname is divided into seven sections (bāb), each of which is devoted to a specific type of supplication. Some chapters are devoted to prayers that need to be recited in momentous events, such as military campaigns or specific dates (Laylat al-Qadr and Yawm 'Arafa/ Arefe Günü, the second day of the Hajj pilgrimage). Others are dedicated to prayers that constitute part of the daily routine of the believer, such as prayers before wearing her garment or eating her meal. Some traditions relate to specific recitations, while others deal with beneficial practices that follow in the Prophet's footsteps. These practices, it should be noted, are also described as $d u$ ' $\bar{a}$ s. Following the Prophet's example, for instance, and his wives 'Â'isha and Hafșa, the earlier shaykhs (meşāyih-imüteḳaddimin) contended that one should start putting on a kaftan with the right sleeve. ${ }^{18}$

The basic unit of the Duanāme are traditions (rivāyet) about or from the Prophet that contextualize the prayer. Consider, for instance, the first rivāyet from the Du'ānāme's first section:

[In Turkish:] Anas ibn Mālik_may God be pleased with him_related: "One day, while the Prophet, peace be upon him, was sitting in the mosque, a person came [to the mosque]. He prayed and recited this prayer: 


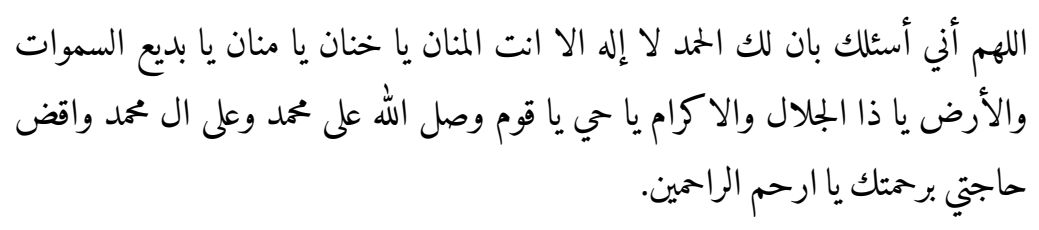

The Prophet — peace be upon him — announced: 'This man recited God's Greatest Name (Hak Te âlānın ism-i a'zamını). Whoever recites [the name] will receive from God whatever he wants." "19

This paragraph illustrates the jurist's understanding of his Du'annāme. The commentary is an act of contextualization of prayers, supplications, and practices within and by a Prophetic tradition, rather than an act of translation and explication of the recited text. Given the şeyhüll-isläm's emphasis on writing the manual in Turkish, presumably with the intention of making it more accessible to non-Arabic speakers, it is remarkable that the content of the supplication remains in Arabic. To put it somewhat differently, once the preconditions for a successful prayer are met, all the supplicant is required to do is to make sure that the prayer she recites matches her goal. She is clearly not expected to understand the words she utters.

Ebū's-su'ūd's Du'ānāme was not unique in its approach to recitation. Other known, as well as anonymous, authors shared the şeyhü'l-isläm's understanding of the act of recitation. The ninth/fifteenth-century scholar and chronicler Şükrullāh (d. 868/1463-1464), for example, in his fairly extensive collection of prayers and supplications (written in Persian), does not stress the importance of understanding the recited prayer. He does, however, include several chapters on the merits of prayer. ${ }^{20}$

19 Ibid. 122.

20 Şükrullāh, Jāmic al-da'wāt. A similar approach can be found in the fairly popular manual by Muhammad ibn Muhammad ibn al-Jazarī (d. 833/1429). Ibn al-Jazarī, 'Uddat al-hiṣn alhașinn. Ibn al-Jazarī was quite popular in the core lands of the empire. A copy of the work was included in Bāyezīd II's library.

It is worth stressing that other tenth/sixteenth-century commentators held a different view from the one found in the chief mufti's Du'ānāme. One of Ebū's-su'ūd's predecessors, the chief mufti Kemālpaşazāde (d. 940/1534), wrote a short commentary on Du'āal-Qunūt, a supplication in Arabic requesting guidance and protection. It is an interwoven commentary (sharh mamzüj) in Arabic, so the text of the prayer is embedded in the commentary. Although Kemālpaşazāde did not write an introduction to the commentary, the fact that he chose to write in Arabic suggests that it was intended to be more exclusive (at least in the core lands of the Ottoman Empire). Indeed, by commenting on Du'ā al-Qunūt, Kemāl- 
Much like their Mamluk counterparts studied by Richard McGregor, Sufis in the core lands of the Ottoman Empire (and well beyond) compiled numerous commentaries on "revealed" or inspired prayers and invocations. In addition, earlier commentaries were still copied throughout the Ottoman period. These commentaries were often associated with a specific Sufi network, as the prayers were "revealed" or at least compiled by senior members of the network. While the prayer commentaries from the Ottoman period still await a more thorough study, some commentaries from the ninth/fifteenth through the twelfth/eighteenth centuries apparently sought to edify reciters who were not necessarily affiliated with a specific Sufi network. But regardless of who the intended audience was, the commentators on invocations and prayers believed that the recited text was not transparent.

The ninth/fifteenth-century jurist and Sufi shaykh Muhyyìd-dīn Muhammed b. Kuṭbe'd-dīn el-İznīkị (d. 885/148o), for example, in the introduction to his commentary on 'Alī b. Shihāb al-Dīn b. Muḥammad al-Hamādanī's (d. 786/ 1385) al-Awrād al-fathiyya, ${ }^{21}$ relates that he was asked to clarify and explain some of the complexities of the Evräd. He adds that he was hoping for an inspiration from the masters (mashayikh) that would assist him in understanding the true or accurate mental content of the evrād (wa-mā huwa al-haqq fi tahquiq ma'ānī al-wird al-mustațāb). Moreover, Kuṭbe'd-dīnzāde explains that the mental content ( $\left.m a^{c} n \bar{a}\right)$ of the evrād are located in multiple places, so he had to examine (muțālaca) them and select the most useful mental content for his fellow Sufis (al-sulaha $\bar{a}^{\prime}$ wa-al-fuqarä) ${ }^{\prime 22}$ And in another commentary on al-Awräd al-fathiyya, one tenth/sixteenth-century (?) Derviş Ca'fer stresses the importance of the commentary for revealing the veracity of the words

paşazāde became part of a long chain of scholars who commented on this supplication (One of the most distinguished members of this tradition is the famous Timurid poet and scholar Jāmī (d. 898/1492)). It appears that his and his colleagues' interest in Du'ã al-Qunūt stemmed, at least in part, from the controversy that accompanied this invocation from as early as the second/eighth century, if not earlier, as different schools of law differed over the text of the $d u^{c} \bar{a}$ and the manner in which the daily prayers should be recited. It therefore seems that the commentaries on Du'a al-Qunüt formed a separate genre. Katz, Prayer 32-33; Haider, The origins, ch. 4. Jāmī, Sharh Dưãa al-Qunūt 4b-6b.

Al-Ḥamadānī was a Sufi master who led an itinerant life across different parts of the Islamic world, including Kashmir, the Hijaz, and Turkistan. al-Awräd al-fathiyya is his best-known compilation. On al-Hamadānī see Stern, 'Alī b. Shihāb al-Dīn b. Muhammad al-Hamadānì. 
(dar vaqt-i tafsīr-i ìn kalimāt shavāhid va bayyināt-izikr karda āyad). ${ }^{23}$ Furthermore, 'Alī b. Ahmmad al-Gūrī, in the introduction to his Kanz al-ibād fi sharh al-awräd, informs his reader that he consulted "the books of high repute and the reliable sayings on the mental content of the words and rules" (min alkutub al-mu'tabara wa-l-aqāwīl al-mu'tamada fì bayān ma'ānī al-lughāt wa-laḥkām). ${ }^{24}$

The Sufi commentators' emphasis on the mental content of the invocations ( $\left.m a^{i} n \bar{a}, \mathrm{pl} . m a^{\prime} \bar{a} n \bar{\imath}\right)$ and its revelation is noteworthy. As opposed to Ebü'ssu'ūd's Du'ānāme, the Sufi prayer commentaries expected the reciter to understand the text she recites, because, as Dervīş Ca fer writes, interpretation is an integral part of recitation. Moreover, interpretation required reading expertise and familiarity with the Islamic hermeneutical disciplines, as the reference to the "books of high repute" and the allusion to 'ilm al-ma'āni, bayān, tafsir, and muțāla'a indicate. As Kātib Çelebi (d. 1068/1657) explains in the entry he devotes in his bibliographic work to the "science of the famous awräd and the revealed supplications" ('ilm al-awrād al-mashhūra wa-al-ad'iya al-ma'thūra), "this is the science of validating and fixing them [the awräd and the supplications] (tașhịhihimā wa-dabțihimā), validating their narration (riwāya), and demonstrating (bayān) their unique features, the number of their repetitions, the times of their recitation and the preconditions [of their recitations]." Moreover, he notes, the goal of this science is to guarantee that the supplications are beneficial (li-yunāl bi-istímālihimā ilā l-fawā̇id al-dìniyya wa-al-dunyawiyya $){ }^{25}$

\section{The Commentaries on 'Alī al-Q̣ārī's al-Hïzb al-ázam and Muhạmmad al-Jazūlī's Dalāil al-khayrāt}

Over the course of the second half of the eleventh/seventeenth and the twelfth/ eighteenth centuries, two compilations of supplications gained considerable popularity across the Ottoman domains, well beyond fairly limited Sufi circles: Muhammad ibn Sulaymān al-Jazūlī's Dalāill al-khayrāt wa-shawāriq al-anwār, a book of prayers on behalf of the Prophet Muhammad, and 'Alī ibn al-Sultān

\footnotetext{
23 Dervīş Ca'fer, Şerh-i Evräd-i Fethiyyye 1b-2a. The manuscript was copied in Istanbul in 960/1552 or 53 .

24 Gūrī, Kanz al-ibād ıb. The manuscript was copied in Istanbul in 984/1576 or 77 .

25 Kātib Çelebi, Kashf al-zunūn i, 200. To the best of my knowledge, the category of 'ilm al-awräd is quite rare (if not unique to the Kashf). On the classification of prayers and invocations in other Ottoman classifications of the sciences see Burak, The section on prayers.
} 
Muhammad Qārī al-Harawī's al-Hizb al-a'zam wa-l-wird al-afkhām, in which he collected supplications from the prophetic traditions. ${ }^{26}$

Muhammad ibn Sulaymān al-Jazūlī was a ninth/fifteenth-century Maghribi Shadhili Sufi and scholar. He apparently composed the Dalāil during his stay in Fez. ${ }^{27}$ Most biographies agree that al-Jazūlì relied on collections of prayers found in the library of the city's Qarawiyyin Mosque, but they disagree on when exactly the compilation of the Dalāil took place. In his authoritative study of al-Jazūlī and his order, Vincent Cornell has suggested that al-Jazūlī wrote the Daläil at some point after his participation in the defense of the city of Tangier in 840/1437. According to several accounts, al-Jazūlī spent time in Medina, where he recited $a h z \bar{a} b$ of the Dalā'il before the Prophet's tomb. ${ }^{28}$ After at least seven years in the Islamic East, during which he apparently learned about Sufi traditions and genres that were not common in the Islamic Far West, al-Jazūlī returned to Fez, where in $857 / 1453$ he penned the initial draft of the Daläil. At the same time, al-Jazūlī gradually recruited a circle of disciples. In Cornell's words, "the cornerstone of Jazulite praxis was the daily recitation of prayers on behalf of the Prophet Muhammad from Daläil al-khayrāt and the morning and noon recitation of al-Jazūlì's Hizb al-falāh (Litany of good fortune)." ${ }^{29}$ Most of the invocations in the Daläil were taken from well-known hadith collections and devotional works, such as Qūt al-qulūb by Abū Ṭālib al-Makkī. ${ }^{30}$ I intend to devote a separate study to the arrival of Dalä'il al-khayrät in the Ottoman lands, but for my purpose here, suffice it to say that by the early twelfth/eighteenth century the Dalāil became extremely popular across the empire, as hundreds (if not thousands) of copies indicate. ${ }^{31}$

26 Occasionally, the Dalä'il and the Hizb were bound together in the same mecmü $a$. See, for example, the mecmū $a$ at the New York Public Library (M\&A, Arab. Ms. 13); and the edition published in Egypt in 1864 by al-Mațbaca al-Kasțaliyya.

27 On al-Jazūlī see Cornell, Realm. On Dalāil al-khayrāt see Witkam, Vroomheid; Barakat et al., Dalä̀il al-khayrāt.

28 Cornell, Realm 174.

29 Ibid. 184.

$30 \quad$ Ibid. 212.

31 By the nineteenth century, Dalä'il al-khayrāt became one of the most popular books in the empire. As Şükrü Hanioğlu has shown in his analysis of the inventories of deceased members of the ruling askerī class for the years 1164/1750-1751 and 1215/1800-1801, Daläil al-khayrāt was owned by members of the imperial ruling elite. Hanioğlu, A brief history 38-40. Similarly, Nelly Hanna argues that in Cairo "[p]rivate libraries in the eighteenth century indicate that it [Daläil al-khayrät] was copied again and again, perhaps more than any other book in the eighteenth century, and was found in a large number of these libraries." Hanna, In praise of books 95. 
Somewhat less popular than the Daläil, though repeatedly copied, was the compilation by 'Alī al-Qārī, one of the most eminent and prolific scholars of the second half of the tenth/sixteenth century. Among his teachers were the famous Shafi'i jurist Ibn Hajar al-Haytamī (d. 974/1566-1567) and the Gujarati 'Alī ibn Ḥusām al-Dīn al-Mutaqqī (d. 975/1567-1568). He was initiated into the Naqshbandi order by Zakariyyā ibn Aḥmad al-Bihārī. 'Alī al-Qārī was also associated with the Bakriyya, a Suf tradition founded by the Bakri family in Egypt. Throughout his career in Mecca, al-Qārī was involved in several polemics and debates with leading Shafi'is and the supporters of Ibn 'Arabī. Moreover, al-Qārì claimed that he was the renovator of Islam (mujaddid) of the Hijri eleventh century. Over the course of the eleventh/seventeenth through the thirteenth/nineteenth centuries, al-Qārī's eminence was widely recognized, at least by Hanafi scholars. ${ }^{32} \mathrm{Al}-\mathrm{Q} a \bar{r} \overline{1}$ wrote on a wide range of topics, including hadith, prophetology, ethics, Quranic exegesis, figh, biography, and tașawwuf. His Hizb al-a'zam is a collection of supplications he collected from hadith compilations. ${ }^{33}$ His works, including the Hizb, have survived in numerous copies and circulated across the Ottoman Empire and the Indian subcontinent.

For the purpose of this essay, it is worth noting that, in the first half of the twelfth/eighteenth century, several commentaries were written on both the Daläil and the Hizb. The commentaries are interwoven (sharh mamzüj) in both texts. ${ }^{34}$ An anonymous twelfth/eighteenth-century addition to Kātib Çelebi's Kashfal-zunūn mentions three commentaries on the Hizb, those of the Meccan Muhạammad ibn Salāma ibn Ibrāhīm al-Mālikī (d. ca. 1144/1731-1732), Ibrāhīm al-Sāqizī/Sāḳızì (completed in 1134/1721-1722), and Shaykh 'Uthmān al-'Uryānī al-Kilīisi (completed in 1144/1731-1732). ${ }^{35}$ In addition to the commentaries mentioned by the anonymous bibliographer, ${ }^{36}$ Muhammad ibn Yūsuf al-İzmīrī completed a commentary on the Hizb in Izmir in 1147/1735, and Muhammad al-Nābulusī al-Azharī completed a fifth commentary in Istanbul in 1142/1730. They all wrote their commentaries in Arabic.

It appears that at least some of the commentators on the Hizb were aware of the fact that in the century that had elapsed since 'Alī al-Qārī had completed his work, no commentary had been written on it. Al-Azharī, for instance, claims

\footnotetext{
32 Franke, 'Alī al-Qārī.

33 For a comprehensive bibliography of 'Alī al-Qārî̀s work, see Shammāe, al-Mullā 'Alīal-Q̄ārī.

34 Some of these commentaries are quite detailed and lengthy, despite the commentators' praise of brevity (ikhtișār) (some commentaries are several hundred folios long). For a survey of the commentaries see Muṣlū, Dirāāāt 'ilmiyya hạwl kitāb Dalāill al-khayrāt.

35 Kātib Çelebi, Kashf al-zunūn i, 66o-661.

36 On the anonymous additions to the Kashf al-zunūn: Burak and Riedel, Did Katip Çelebi.
} 
that he and his colleagues were not aware of a commentary on the Hizb. ${ }^{37}$ Similarly, al-Mālikī decided to write his commentary in response to questions he had received from different parts of the Islamic lands, including Rum and Bilad al-Sham, concerning the traditions in the Hizb. Other commentators also sensed a need to interpret the Hizb: in the introduction to his commentary, after singing praises to the work, Sāklzì explains that it occurred to him to write a comprehensive commentary (sharh) on the text so that those who seek the knowledge (al-țälibin al-räghibìn) would benefit from it. ${ }^{38}$ "I wrote a commentary," his colleague Muḥammad ibn Yūsuf al-İzmīrī writes, "to propagate its essence (jawāhir) and to demonstrate its inner sides (damāir its expressions, and to expose its signs." Al-i̇zmīnī, too, claims to have written the commentary in an abbreviated style (wujh al-ikhtișär) for those who seek knowledge (al-țälibìn, al-räghibìn). ${ }^{39}$

One of the intriguing aspects of the introductions is that the intended readership of the commentaries was fairly broad. As we have seen, Sākızì intends the commentary to be consulted by "those who seek knowledge." Al-İzmīrī, in addition to the seekers of knowledge, hopes that his commentary will be read by madrasa professors and teachers (mudarris wa-mu'allim), and al-'Uryānī dedicated his commentary to the vizier. ${ }^{40}$

The first half of the twelfth/eighteenth century also witnessed the appearance of the first Ottoman commentaries on Daläil al-khayrāt. In the case of the Daläil, unlike that of the Hizb, an important and well-known commentary was written in the late eleventh/seventeenth century-Muhammad al-Fāsìs Mațālic al-massarāat bi-jalā̉ Dalāil al-khayrāt. Al-Fāsī was one of al-Jazūlī's disciples, and his commentary, which is also a documented collation of numerous Maghribi manuscript copies of the Dalẩil, including the most authoritative copy (known as al-Nuskha al-Sahliyya), left its mark on the Ottoman Daläil commentaries and was copied repeatedly in the Ottoman lands. ${ }^{41}$ The Ottoman commentaries, however, seem to have been a response to a different set of concerns and anxieties.

37 Azharī, al-Kāshif li-ad'iya 2a-b. The colleagues al-Azharī consulted were Khalīl ibn Muṣțafā of Diyarbakr and 'Alī al-'Iryān.

38 Sākızī, Fayḍ al-arham ıb-2a.

39 İzmīrī, Fath Allāh $\mathrm{ib}-2 \mathrm{~b}$.

40 İzmīrī, Fatḥ Allāh 2a; 'Uryānī, Sharh al-Hizb ib.

41 The anonymous twelfth/eighteenth-century bibliographer who added to the entry on the Dalāill in Kātib Çelebi's Kashfal-zunūn celebrates al-Fāsì's commentary: "Dalāil al-khayrāt wa-shawāriq al-anwār fì dhikr al-șalāt 'alá al-nabī al-mukhtār ... by the shaykh Abū 'Abd Allāh Muhammad ibn Sulaymān ibn Abī Bakr al-Jazūlī al-Samallānī al-sharīf al-Ḥasanī, who died in $854[\mathrm{AH}]$. This book is one of the signs of God about the prayer upon the 
As opposed to the commentaries on the Hizb, which were written to the best of my knowledge exclusively in Arabic, commentaries on the Daläil were written in both Ottoman Turkish and Arabic. The production of Turkish commentaries on the Daläil attests to the immense popularity of the work throughout the Turkish-speaking parts of the empire..$^{42}$ As the early twelfth/eighteenthcentury commentator Kara Dāvud (d. 1170/1757?), ${ }^{43}$ whose commentary on the Daläil was probably the most popular one, states, "the numerous merits of the Daläil are well known to both commoners and the elite." ${ }^{44}$ At the same time, it seems that Kara Dāvud thought that the popularity of the Daläil required an accessible commentary. Even though he did not think that understanding the mental content of the recited text was a prerequisite: "According to the noble madhhab of the master of our madhhab, the Great Imam and the first magnanimous [scholar], Abū Ḥanīfa Nu'mān ibn Thābit al-Kūfì, [God's] mercy be upon him, it is not a precondition to know the mental content [of the words] while reciting wirds, dhikrs and supplications (evrād ve ezzkār ve ed'iyeler okundukta ma'nāsın bilmek şart olmayub), but there is no doubt that there are rewards and great benefits in pronouncing [the words] correctly and without mistakes."

Prophet. It is being repeatedly recited in the eastern and western [Islamic lands], including in the Lands of Rum. There is an elegant interwoven commentary on [the Daläil] by the shaykh Muhammad al-Mahdī ibn Aḥmad ibn 'Alī ibn Yūsuf al-Fāsī al-Q̣aṣawī, who died in 1052 [/1642-1643], titled Mațāli' al-masarrāt bi-jalā' Dalāill al-khayāt." Kātib Çelebi, Kashf al-žnūn i, 759. On al-Fāsī's commentary and its Ottoman readers, see Burak, Collating the signs of benevolent deeds. Moreover, in the first half of the twelfth/eighteenth century, one Muhammed Emīn el-Tokātī penned an abridged adaptation/translation into Ottoman Turkish of al-Fāsīs commentary. Tokātī, Tercüme. Moreover, a commentary by Muhammad ibn Aḥmad al-Sharîf al-Jazāirī on al-Fāsīs commentary (which was wrongly attributed to Muhammad ibn Velī ibn Resūl el-Kirşehrī el-İzmirī) was copied at least three times in the Ottoman lands in the first half of the twelfth/eighteenth century. In the introduction the commentator explains that he consulted Abū 'Abd Allāh al-'Arabī al-Fāsī's hăshiyya on the Dalāil and Muhammad al-Mahdī al-Fāsì's sharh, and thought the former was too lengthy and left many issues unclear, whereas the other "tended to spread" (mäla ilä al-basț ). He therefore decided to write a short commentary on these works. [Jazā'irī,] Istijlāb $1 \mathrm{~b}-2 \mathrm{a}$. The other copies are Süleymaniye Kütüphanesi, Ms Nuruosmaniye 968 and Beyazıt Devlet Kütüphanesi, Ms Veliyüddin Efendi 665.

42 Commentators from the Arabic-speaking lands of the empire wrote the commentaries in Arabic. 'Abd al-Mu'țī ibn Salīm ibn 'Umar al-Shiblī al-Simillāwī (d. 1127/1715) completed in Egypt an Arabic commentary on the Daläil. Simillāwī, Tafrịh. Similarly, Rīhāwī Muhammad b. Sulaymān al-Ḥalabī wrote his commentary, titled Muntij al-barakāt 'alā Dalāìl al-khayrāt (Süleymaniye Kütüphanesi, Ms Süleymaniye 254).

43 On Kara Dāvud, see Arpaguş, Kara Dāvud.

44 At least one member of the imperial ruling elite, the grand vizier Ḥekīmoğlu 'Alī Pasha (d. $1171 / 175^{8}$ ) appears to have had keen interest in the Dalä'il, as he was the dedicatee of Rīhāwī Muḥammad b. Sulaymān al-Ḥalabī’s commentary. 
But, he assures his reader, "the reward is greater if [one] recites [the Daläil] while paying attention to the elegant mental content (ma'nā-i latîfi mülāhaze ile okunmasında ecr dahiziyäde olub), and its benefits will be more evident and clearer." Therefore, he concludes, he decided to write an abbreviated (vechü'lihtișār) commentary in Turkish. ${ }^{45}$

Another commentator, Meḥmed Şākir ibn Sun'ullāh el-Anḳaravī (d. 1172/1758 or 59?), informs his reader in the Arabic introduction to his Turkish commentary that he decided to write the commentary when he saw that many seekers of knowledge (räghibinn) read the Dalāil without knowing Arabic. He was concerned that for this reason they unwittingly changed the mental content of the text and erred without noticing. Furthermore, he warns his readers, that understanding the mental content of the recited text is crucial and that "it is forbidden to recite phrases of which he does not know the mental content." He also encourages his reader to collate the manuscript he is consulting with the copy of his teacher. To remedy this grave situation, el-Anḳaravi undertook the writing of a "commentary in Turkish (sharh Turkī) to explain the structure [of the Daläil], to interpret its meaning, to elaborate on the entire [work], to illustrate its details, and to reveal its hidden secrets." ${ }^{46}$

To sum up, the interest of the twelfth/eighteenth-century commentators on the Daläil and the Hizb in making the text accessible, and their emphasis on understanding the mental content of the recited words is profoundly different from the approach of Ebü's-su'üd Efendi and more in line with the approach prevalent in Sufi circles concerning their respective invocations and prayer cycles. What is more, as I have already pointed out, throughout the eleventh/seventeenth century, the Hizb and, in the second half of the same century, the Daläil did not draw the attention of commentators from the Ottoman lands, whereas the early decades of the twelfth/eighteenth century saw the publication of a significant number of commentaries on these works. Again, this is not to say that the approach to the prayer/invocation found in Ebū's-su'ūd Efendi's Du'ānāme was completely replaced by the commentaries' ideal of comprehending the recited text. The commentaries, however, seem to reflect the growing popularity of the ideal of recitation that, until the late eleventh/seventeenth century, prevailed in narrower circles. This qualitative and quantitative change requires explanation.

45 Kara Dāvud, Şerḥ-i Delā̉il 5. In the same vein, in 113o/1717-1718, İbrāhīm b. Ṣaliḥ el-ḳıbrısī relates that he wanted to write an abbreviated and useful commentary in Turkish, so that

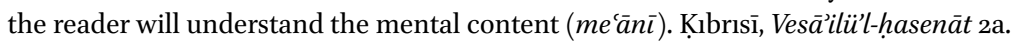



upon the Earth." (Q 7:146)

Relatively little scholarly attention has been paid to Ottoman piety in the late eleventh/seventeenth century, and even less in the first decades of the twelfth/eighteenth century. In her study of Ottoman prayer manuals, Christiane Gruber has linked the appearance of numerous Ottoman devotional texts to attempts of political and social reforms in the empire and to the "deployment of the rather malleable concept of renewal (tajdid)." ${ }^{47}$ It is possible that new ideas about renewal and revival encouraged scholars to compile devotional texts and commentaries in an attempt to generate a new Muslim subject. Much more work, however, remains to be done to establish how exactly twelfth/eighteenth-century notions of renewal shaped the production of devotional texts and commentaries in this time period.

At the same time, it is possible that the appearance of the commentaries had very little to do with the notions of reform and revival. The fact that the commentators on the $\mathrm{Hiz} b$ and the Daläil do not allude to the discourse of renewal may further question this connection. It appears that a more immediate reason for writing commentaries in the early twelfth/eighteenth century was the growing popularity of invocations and prayer cycles and, perhaps, the circulation of apocryphal invocations. Consider, for example, the following passage from Tartīb al-'ulüm (completed in 1128/1716) by the prominent scholar and Qadiri and Naqshbandi ${ }^{48}$ Sufi Muhammed Saçaḳlızāde:

This wretched poor [i.e., the author] says: We have witnessed several people who are considered accomplished [reciters, yusammā bi-l-takmïl], [but] are unable to recite the Quran [adequately] to have a proper prayer that is legally valid. This contradicts piety $(\operatorname{taqw} \bar{a}) /$ the most accepted legal opinion $(f a t w \bar{a}) .{ }^{49}$ This [recitation] undermines piety from its foundations. [This reciter] refrains from uncertainties while corrupting [his] prayer five times a day. He takes a portion of the Quran as his daily act of recitation [in his prayers, yattakhidhü min al-Qur'ān wirdan] while worshiping God through misdeeds. Meanwhile, he is ashamed to be seen

Gruber, A pious cure-all 120-123 (and the bibliography therein). On the circulation of Ahmad Sirhindī's notion of tajdìd in the Ottoman Empire in the late seventeenth/early eighteenth centuries, see Pagani, Il rinnovamento.

48 Kurz, Ways to heaven 53 .

49 The editor of the text believes it should be fatwa and not taqwāa, as it appears in most copies of Tartīb al-'ulüm. 
sitting with a large turban with other ulama in front of an instructor from those who are [allowed] to recite [the Quran, ahl al-ad $\bar{a}$, that is, a real scholar], claiming that this [the recitation] is the duty of the novices (wazäaif al-mubtadīin), because [he thinks] he has become one of the most senior professors (al-mudarrisin al-fudalä). "Woe to you, and woe! Then woe to you and woe!" (Q 75:34-35). He the Most High said: "I shall turn away from My signs those who are unduly arrogant upon the earth." $(\mathrm{Q} 7: 146) .^{50}$

The passage reflects Saçaklızāde's (and probably others') concern about the level of Arabic of many readers of the Quranic text, on which many supplications and prayers draw. The identity of the reciter who is the target of Saçaklizāde's accusations is unknown. It seems, however, that Saçaklızāde thought this was not a problem with a specific individual but a broader phenomenon. In any case, this accusation echoes the concerns expressed by at least some commentators who were worried that people do not recite their invocations properly and/or lack understanding of the texts they recite. In other words, it appears that the popularity of both the Hizb and the Daläil (and possibly other devotional works) beyond the narrow scholarly/Sufi circles drove scholars to invest considerable efforts to cultivate more responsible reciters. To this end, they resorted to (and popularized) the fairly well-established genre of the Sufi prayer commentary.

\section{6}

\section{Conclusion}

In this short essay I have tried to examine how different commentators perceived the relationship between understanding the prayers, devotional texts and invocations, and the recitation's efficacy. While it is clear that these commentaries/manuals offer a unique glimpse into the Ottoman religious landscape, it is still unclear how the devotional sensibilities these texts reveal relate to one another. Specifically, it is still not fully clear what perception was more prevalent in what circles. Moreover, as the academic study of Ottoman devotional literature is in its early stages, the conventions employed in different genres remain to be studied. At this point, I am inclined to believe that multiple perceptions coexisted throughout the Ottoman domains. It appears

$5^{\circ}$ Sājaqlīzādah (Saçaḳlızāde), Tartīb al-'ulūm. I am grateful to Walid Saleh for his assistance in translating this passage. 
to me, however, that over the course of the eleventh/seventeenth and the twelfth/eighteenth century, the perception that recommended, or even demanded, understanding of the prayer's text became increasingly popular, at least among the learned. The concerns about proper understanding of the text and its mental content may be situated in a broader set of concerns about the nature of belief and intention, which are examined in Tijana Krstićs chapter in this volume, and the attempts of Ottoman jurists to determine the relationship between inner faith and its manifestations. ${ }^{51}$

Be it as it may, in the context of the historiography on confession building in the Ottoman lands, in which the Ottoman dynasty, its administrative elite, and learned hierarchy play a central role, the large textual corpus of prayers and invocations draws attention to other registers of Ottoman Islam. In certain instances, as was the case with Ebü's-su'ūd, a member of the administrative elite commissioned or was the dedicatee of the manual. But in many other cases, the Ottoman dynasty and individuals who were affiliated with it were significantly less dominant. In other words, paying attention to the enormous textual body of prayers and invocations, much like other textual corpora from the Ottoman lands, may enable scholars of the history of confession building in the Ottoman domains to examine it beyond the purview of the dynasty and its administrative elite.

\section{Bibliography}

\section{Primary Sources}

Ankaravī, Meḥmed Şākir ibn Sun'ullāh, Sharh al-Dalāill, Süleymaniye Kütüphanesi, MS Fatih 711.

Azharī, Muḥammad al-Nābulusī, al-Kāshif li-ad'iya al-nabī al-akram, sharh al-Hizb ala'zam wa-al-du'ā al-afkham, Süleymaniye Kütüphanesi, Ms Nuruosmaniye 2883.

Dervīş Ca'fer, Şerh-i evrād-ifethiyye, Süleymaniye Kütüphanesi, Ms Fatih 2657.

Gūrī, 'Alī b. Ahmad, Kanz al-ibād fı̀ sharh al-awrād, Süleymaniye Kütüphanesi, ms Nuruosmaniye 2532.

Ibn al-Jazarī, Uddat al-hiṣn al-ḥașinn min kalām Sayyid al-Mursalīn, Cairo 2007. İzmīnī, Muhammad ibn Yūsuf, Fath Allāh al-a lam fì kashf asrār al-Hizb al-a'zam, Süleymaniye Kütüphanesi, MS Atif Efendi 1538.

İznīḳī, Muhyīddīn Muhammad b. Kuṭ̣beddīn, Şerh-i evrād-i fethiyye, Süleymaniye Kütüphanesi, MS Haci Mahmud Efendi 4093.

$5^{1} \quad$ Burak, Faith, law and empire. 
Jāmī, Nūr al-Dīn 'Abd al-Raḥmān ibn Aḥmad al-Khurāsānī, Sharḥ du'ā al-Qunūt, Süleymaniye Kütüphanesi, Ms Kasidecizade 757 .

[Jazāirī, Muḥammad ibn Aḥmad al-Sharīf], Istijlāb al-masarrāt bi-sharḥ Dalāill alkhayrāt, Süleymaniye Kütüphanesi, ms Nuruosmaniye 967 .

Kaleli, A., Du'ā-nāme (inceleme-çeviri yazılı metin-özel adlar dizini-tipkibasım), MA thesis, Adıyaman Üniversitesi 2014.

Kara Dāvud, Şerḥ-i Delā'ilül-hayrāt, [Istanbul] 1857.

Kātib Çelebi, Kashf al-z̧unūn 'an asāmīal-kutub wa-al-funūn, 2 vols., Istanbul 1971-1972.

Ḳıbrısî, İbrāhīm ibn Sāliḥ, Vesā̉ilüll-ḥasenāt fi şerḥi Delā'li'l-hayrāt, Süleymaniye Kütüphanesi, Ms H. Hüsnü Paşa 754.

Rīhḥāwī, Muḥammad b. Sulaymān al-Ḥalabī, Muntij al-barakāt 'alā Dalā̉il al-khayrāt, Süleymaniye Kütüphanesi, Ms Süleymaniye 254 .

Sājaqlīzādah (Saçaḳlızāde), Tartīb al-ulūm, ed. M. Aḥmad, Beirut 1988.

Sakızī, Ebu İshāk ibn İbrāhīm ibn 'Abdullāh, Fayḍ al-arham wa-fatḥ al-akram 'alá alHizb al-ązam wa-al-wird al-afkham, Süleymaniye Kütüphanesi, Ms Haci Selim Ağa 503 .

Simillāwī, 'Abd al-Mu'țī ibn Salīm ibn 'Umar al-Shiblī, Tafrīh al-qurab wa-al-muhimmāt bi-sharḥ Dalāil al-khayrāt, Süleymaniye Kütüphanesi, Ms H. Hüsnü Paşa 183.

Şükrullāh ibn Şihābe'd-dīn Aḥmed, Jāmi` al-da'wāt, Süleymaniye Kütüphanesi, MS Fatih 2774.

Toḳātī, Muḥammed Emīn, Tercüme-i şerhh-i Delāili'l-Hayrāt, Süleymaniye Kütüphanesi, Ms Halet Efendi 70.

'Uryānī, 'Uthmān, Sharḥ al-Hizb al-ażam, Süleymaniye Kütüphanesi, Ms Vahid Paşa 318.

\section{Secondary Sources}

Ahmed, A.Q. and M. Larkin, The hashiya and Islamic intellectual history, in Oriens 41 (2013), 213-216.

Artan, T., Forms and forums of expression: Istanbul and beyond, 16oo-180o, in C. Woodhead (ed.), The Ottoman world, Hoboken 2011, 378-405.

Bain, A., The late Ottoman En'am-ı şerif: Sacred text and images in an Islamic prayer book, PhD diss., University of Victoria 1999.

Barakat, H.N. et al., Daläil al-khayrāt: Prayer manuscripts from the 16th to 19th centuries, Kuala Lumpur 2016.

Burak, G. and D. Riedel, Did Katip Çelebi write Kashf al-z̧unūn?, paper presented at All you can do with catalogs: Accessing, organizing, disseminating local and global knowledge (15th-19th centuries) workshop, Forum Transregionale Studien and Staatsbibliothek zu Berlin, 6-7 October 2016.

Burak, G., Between Istanbul and Gujarat; Descriptions of Mecca in the sixteenthcentury Indian Ocean, in Muqarnas 34 (2017), 287-320. 
Burak, G., Collating the signs of benevolent deeds: Muḥammad Mahdī al-Fāsī's commentary on Muhammad al-Jazūlì's Dalā'il al-khayrāt and its Ottoman readers, in Philological encounters 4 (2019), 135-157.

Burak, G., Faith, law and empire in the Ottoman "age of confessionalization" (fifteenthseventeenth centuries): The case of "renewal of faith," in Mediterranean historical review 28 (2013), 1-23.

Burak, G., The section on prayers, invocations, unique qualities of the Qur'an and magic squares in the Palace Library inventory, in G. Necipoğlu, C. Kafadar and C. Fleischer (eds.), Treasures of knowledge: An inventory of the Ottoman palace library (1502/31503/4), Leiden 2019, 341-366.

Cornell, V.J., Realm of the saint, Austin 1998.

Demir, A., Devlet-i aliyye'nin büyük hukukçusu Şeyhülislam Ebussuud Efendi, Ankara 2006.

Franke, P., 'Alī al-Qārī, $E I^{3}$.

Gruber, C., A pious cure-all: The Ottoman illustrated prayer manual in the Lilly Library, in C. Gruber (ed.), The Islamic manuscript tradition: Ten centuries of book arts in Indiana University collections, Bloomington 2010, 116-153.

Haider, N.I., The origins of the Shi'a: Identity, ritual, and sacred space in eighth-century Kufa, Cambridge and New York 2011.

Hanioğlu, M.Ş., A brief history of the late Ottoman Empire, Princeton 2010.

Hanna, N., In praise of books: A cultural history of Cairo's middle class, sixteenth to the eighteenth century, Syracuse 2003.

Hirschler, K., The written word in the medieval Arabic lands, Edinburgh 2012.

Kelepetin Arpaguş, H., Kara Dāvud, TDViA, xiv, 359.

Katz, M., Prayer in Islamic thought and practice, Cambridge and New York 2013.

Key, A., Language between God and the poets: Ma'na in the eleventh century, Berkley 2018.

Krstić, T., From shahāda to 'aqìda: Conversion to Islam, catechization, and Sunnitization in sixteenth-century Ottoman Rumeli, in A.C.S. Peacock (ed.), Islamisation: Comparative perspectives from history, Edinburgh 2017, 296-314.

Kurz, M., Ways to heaven, gates to hell: Fażlizzāde 'Alìs struggle with the diversity of Ottoman Islam, Berlin 2011.

McGregor, R., Notes on the literature of Sufi prayer commentaries, in MSR 17 (2013), 199-211.

Muṣlū, R., Dirāsāt 'ilmiyya ḥawl kitāb Dalāil al-khayrāt li-Muḥammad bin Sulīmān alJazūlī fī 'ahd al-dawla al-'Uthmāniyya fī al-Anāḍūl, in A. Bilqāọī (ed.), Aḥmad bin Sulìmān al-Simlālì al-Jazūlì: Rā'id al-tajdīd al-șūfì fì Maghrib al-qarn al-tāsi` al-hijrī, Agadir 2013, 447-466.

Padwick, C.E., Muslim devotions: A study of prayer manuals in common use, London 1961.

Pagani, S., Il rinnovamento mistico dell'Islam: Un commento di 'Abd al-Ghani al-Nabulusi a Ahmad Sirhindi, Naples 2003. 
Shammā̄e M., al-Mullā 'Alīal-Qārī: Fihris mu'allafātihiwa-mā kutiba 'anhu, Dubayy 1993. Stern, S.M., 'Alī b. Shihāb al-Dīn b. Muḥammad al-Hamadānī, in $E I^{2}$.

Terzioğlu, T., Where 'ilm-i hâal meets catechism: Islamic manuals of religious instruction in the Ottoman Empire in the age of confessionalization, in Past and present 220 (2013), 79-114.

van Lit, L.W.C., An Ottoman commentary tradition on Ghazali's Tahafut al-falasifa; Preliminary Observations, in Oriens 43 (2015), 368-413.

Witkam, J.J., Vroomheid en activism in een islamitisch gebedenboek: De geschiedenis van de Dala'il al-Khayrat van al-Gazuli, Leiden 2002. 